\title{
Ductility Evaluation of Steel Structures with Reduced Beam Sections and Post-Tensioned Cables Using the Finite Element Method
}

\author{
Esmaeil Hashemi Mehr \\ Civil Engineering (Structural Engineering) Dpt, \\ Faculty of Engineering, Islamic Azad University of Arak, \\ Arak, Iran
}

\author{
Hamid Reza Saba \\ Amirkabir University of Technology \\ Tehran, Iran
}

\begin{abstract}
Given the importance of structure strengthening, this research introduces a particular type of steel structure in which the reduced beam section and post-tensioned cables were used for creating centralized property and preventing the formation of plastic hinges in the beam and columns. After introducing the system, ABAQUS modeling results are compared with a reliable laboratory sample to check its accuracy. Good convergence was seen which shows the modeling accuracy. The results of the model's nonlinear static analysis revealed that the above steel structure has higher ductility when compared to conventional steel structures. Also, the results showed that with the rising of height, span length and early post-tensioned power of the cables we can increase the ductility of the structure.
\end{abstract}

Keywords-post-tensioned cables; reduced beam section; ductility.

\section{INTRODUCTION}

The importance of designing resistant structures against the lateral forces is a crucial matter in Iran. In recent years, according to urban development and construction progress in the country, the attention to the issue of earthquakes and the importance of wind power in high-rise buildings has been a serious issue. The clamped connections of steel structures in Northridge earthquake (1994) and Kobe earthquake (1995) showed poor performance and generally sustained the brittle fracture of the weld flange of the beam to the column. Looking for a solution to avoid similar cases in the future, the researchers presented the connections of reduced beam section (RBS). In 1996 the direct connection was invented, and then its shape according to bending moment diagrams was modified under lateral load effects. Afterwards, the linear reduced beam section was created. Another type of this connection was introduced as a linear radial connection in late 1998. Finally, the radial cutting connection was proposed [1]. The results of the comparison experiments of steel moment frames to conventional bending and reduced section show that the moment frames with RBS connections are better than conventional bending frames. The behavior factor is one of the most important design parameters and in fact, it is the impact of ductility in the elastic design of the structure. Therefore, recognition of such criterion is very important for the lateral systems. One of the main objectives in the design of steel structures is failure of the connecting place as the last stage of structural collapse, after the failure of beams and columns. But in recent earthquakes, failure of connections occurred before the one of beams and columns. In fact, while rigid connections have high resistance and hardness, the performed studies indicate that their low ductility causes the premature rupture [2]. After the Northridge earthquake, extensive studies in the field of steel moment connections for increasing the ductility and reducing damage to the main members were performed. The result is the introduction of rigid connections with higher ductility due to the receding of the plastic hinge from junction place [3] and various screw connections [4]. In this direction, a new type of steel connection inspired by the idea of posttensioned precast concrete connections was introduced in [5]. In the proposed connection, the cable was used to create bending, shearing resistance, and restoring force. In a system with post-tensioned connections, instead of conventional reinforcements, a series of cables (tendons) with high tensile strength are used. These cables are placed under great tension at the two ends of the beam. Thus, post-tensioned cables after releasing tend to shrink and achieve the primary mode.

Today, the moment frames with new connections are expected to tolerate the large inelastic deformations in beams and columns that occur in great earthquakes, though the disadvantages of new procedures designed steel frames are the formation of the plastic hinge and local buckling in the structural elements in large earthquakes. Permanent non-elastic deformations in beams and columns create large drifts which lead to loss of structural function. In contrast, in the centralist structures, the significant non-elastic deformations and residual drift in beams and columns can be deleted by the opening of the connection distance. Therefore, it seems that the centralist structures can, without damage to the main structural members, return to their original position after the earthquake. Unlike the conventional steel frames which are based on the ductility and endurance of structural materials, ductility behavior of the centralist structures is constant because of the behavior of posttensioned cables or high quality fittings. In these connections before the cyclic loading, the strong cables or fittings become post-tensioned. Due to post-tensioned force at the cables during 
an earthquake, these cables tend to turn back the structure to its original position (before the earthquake). It should be noted that in order to the structure to be able to maintain its centralization property, the post-tensioned cables and the main connection parts should remain in the elastic form [6]. What this study seeks, is evaluating nonlinear behavior of steel structures in which, the type of connection being used is a combination of reduced beam section and post-tensioned cables. Also, we are trying to investigate the effect of important seismic parameters such as height, span and primary posttensioned power of cables.

\section{MODEL VALIDATION}

In this study, the presented model in [7] was used. The analyzed connection type in the laboratory by authors of [7] was in the cross-shaped form and it was made by two beams in two sides of a column, cable, corner and amplifier, forehead, double and continuity plates. The beams at the free end have a rollers support and the column at the law part has a joint support and it is free at the top. These conditions are based on the intersection points of the beams and columns in frames under lateral load. The height of the used column in connection sample is $3962 \mathrm{~mm}$ and its total length, including two beams and column section height, is equal to $8992 \mathrm{~mm}$. The made connection sample that is ready for loading in the laboratory is indicated in Figure 1. The analytical model and its geometric characteristics are similar to vitro model modeled by finite element software ABAQUS. The cable modeling faces many problems, because of the happening of numerous buckling and the entrance of the plate to the area after buckling. Analysis type can have a significant impact on the results thus the theory of large deformations is used. In Figure 2 results of the modeling in ABAQUS software are compared with the laboratory sample results.

\section{A. Introduction of the Case Study Model}

The case study model is a one- floor and one- span type of frame. The explanation of its properties explained in [8]. The beams are IPE40 and the axis to axis length is 4 meters. The columns are IPB34 and the axis to axis is length 2 meters. The post-tensioned cables have $20 \mathrm{~mm}$ inner diameter, and the holder diameter of $30 \mathrm{~mm}$. The length of each cable is 4.33 meters. The primary post-tensioned force of each cable is 40 KN. Fastener screws of the corners to beam and column are the A490 type and their body diameter is $30 \mathrm{~mm}$ and holder diameters are $40 \mathrm{~mm}$. The region soil is type III. The mechanical properties of the materials used in modeling are expressed in Table I. The connection of the corners to beam flange and the column flange, was made with 2 and 4 high strength screws respectively. For connecting the hardeners to beam flange the weld has been used. Figure 3 indicates the way of the beam connection to a column. As you see in this system for connecting the beam to the column, the corner on the top and bottom of the beam is used as well as steel cables with high resistance. These cables are placed along with the beams and pass through the column flanges and finally they hold outside of the connection area. As an effect of cable controlling, a primary tensile force is created, the connection members go under pressure and an initial bending moment is created in the connection. It should be said that the beams and columns are not directly connected to each other and there is $2 \mathrm{~cm}$ distance by the column flange hardener [9].

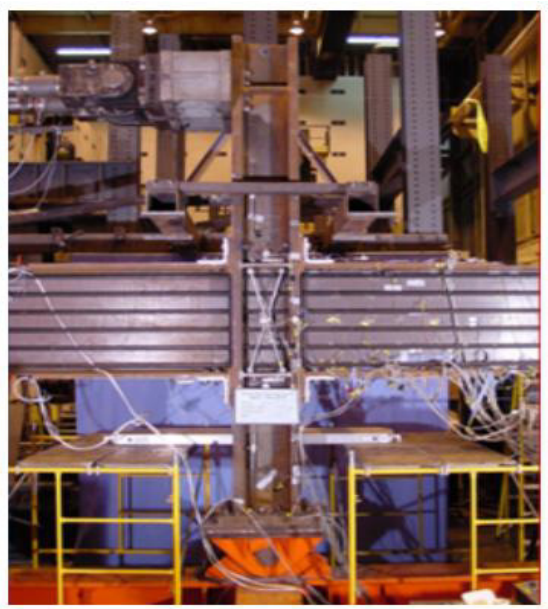

Fig. 1. The laboratory sample used to measure model validation

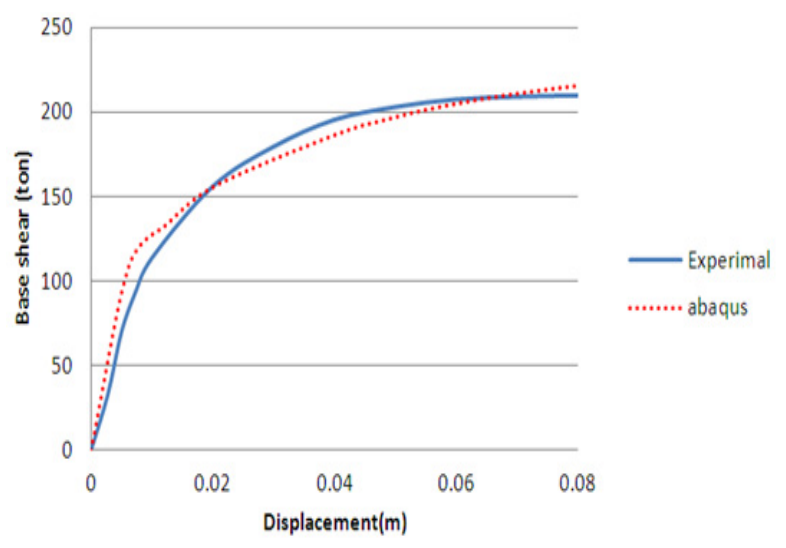

Fig. 2. The load chart_ lateral displacement of the laboratory samples and finite element model

TABLE I. MECHANICAL PROPERTIES OF THE CASE STUDY STEEL FRAME MATERIALS

\begin{tabular}{|c|c|c|c|c|}
\hline Material type & E (GPa) & Fy (MPa) & Fu (MPa) & v \\
\hline $\begin{array}{c}\text { Beam, column } \\
\text { and Hardener }\end{array}$ & 210 & 345 & 520 & 0.3 \\
\hline Cable & 210 & 1120 & 1400 & 0.3 \\
\hline Screw & 210 & 854 & 913 & 0.3 \\
\hline
\end{tabular}

\section{B. Element and the Brigade Networking}

The used element in the structural parts modeling is the solid type. This element is three-dimensional. It is in two forms of wedge and square. It loads any general form under any loading. This element can tolerate the tension, pressure, bending and turning. It is used for modeling solid objects. The continuum brigade networking is used in the modeling. This kind of element is considered as standard volumetric elements in ABAQUS. 


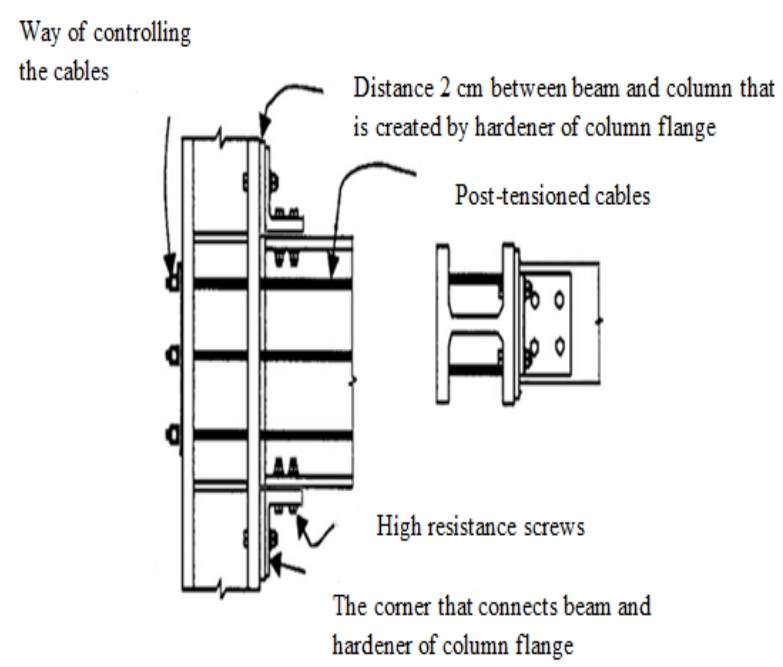

Fig. 3. The way of connecting the beam to column in the steel frame system that has post-tensioned cables

\section{Way of Loading}

Loading type is nonlinear static. In this kind of loading after moving in the form of cycling during 13 cycles to the top of the columns, the hysteresis chart is drawn and through it, the pushover chart of the structure. After that, the ductility of the structure is determined by converting the pushover chart to a two-line chart by using the related relationships.

\section{Ductility Factor $(\mu)$}

Ductility factor of the structure is the maximum lateral shift ratio to the lateral movement like yielding (1). The ductility factor of a structure indicates the entrance rate of the structure to the non-linear zone.

$\mu=\Delta \max / \Delta y$

$\Delta \max$ is the maximum lateral displacement and $\Delta y$ is the lateral displacement like the structural yield limit. In order to determine the ductility value and ductility factor firstly we should convert the pushover chart of the structure into two linear charts using a simple two-line method [6]. Afterwards we can estimate the values of ductility and ductility factor.

\section{RESULtS}

\section{A. Evaluation of Ductility Factor}

For the evaluation of ductility factor of a steel frame that has reduced beam section and post-tensioned cables in comparison with the normal frame, we consider a steel frame with cable and a normal frame without cable and the manner of connecting all of its parts by welding. They are similar to the steel frame with cable in the aspect of materials kind and size, loading circumstance and modeling. Both of the model's length from axis to axis is 4 meters and primary post-tensioned force is $40 \mathrm{KN}$. After the modeling, both models go under non-linear static analysis. Table II indicates the movement of yielding, resistance and ductility in both of the models.
TABLE II. COMPARISON OF THE MOVEMENT OF YIELDING, RESISTANCE AND DUCTILITY OF THE NORMAL STEEL FRAME AND STEEL FRAME WITH CABLE

\begin{tabular}{|c|c|c|c|}
\hline Type of the steel frame & $\boldsymbol{\Delta y}(\mathbf{m})$ & $\boldsymbol{\Omega}$ & $\boldsymbol{\mu}$ \\
\hline Normal & 0.0067 & 1.52 & 13.53 \\
\hline With cable & 0.0063 & 1.53 & 14.66 \\
\hline
\end{tabular}

According to Table II, the steel frame with cable has higher ductility factor in comparison with the normal steel frame. Therefore, we can increase the rate of ductility factor and consequently the seismic function of structures by using the post-tensioned cables in steel frames.

\section{B. Investigation of the Effects of Height on the Ductility Factor}

For the investigation of the height effect on the ductility factor of the structure, we consider three models of the steel frame with cables with heights of $2.7,3.7,4.7 \mathrm{~m}$ consecutively. The length of the span from axis to axis is 4 meters and posttensioned force is $40 \mathrm{KN}$. The results of non-linear statistical analysis of the models are expressed in Table III.

TABLE III. EFFECT OF HEIGHT ON THE DUCTILITY FACTOR OF STEEL FRAME WITH CABLE

\begin{tabular}{|c|c|c|c|}
\hline Type of the steel frame & $\Delta \mathbf{y}(\mathbf{m})$ & $\mathbf{\Omega}$ & $\boldsymbol{\mu}$ \\
\hline $\begin{array}{c}\text { Steel frame with cable with the } \\
\text { height of } 2.7 \mathrm{~m}\end{array}$ & 0.0063 & 1.53 & 14.66 \\
\hline $\begin{array}{c}\text { Steel frame with cable with the } \\
\text { height of } 3.7 \mathrm{~m}\end{array}$ & 0.0052 & 1.26 & 17.75 \\
\hline $\begin{array}{c}\text { Steel frame with cable with the } \\
\text { height of } 4.7 \mathrm{~m}\end{array}$ & 0.0051 & 1.24 & 17.97 \\
\hline
\end{tabular}

According to the results of the Table III, the larger value of ductility factor is related to the model with the height of $4.7 \mathrm{~m}$ and the smaller value of ductility is for the model with the height of $2.7 \mathrm{~m}$. Therefore, the height affects the rate of ductility factor of steel frame with cable. We can increase the structure's rate of ductility factor by raising the height.

\section{Evaluation of the Effect of the Length of the Span on the Ductility Factor}

In order to evaluate the effect of the length of the span on the ductility factor, we consider three models of steel frames with $2.7 \mathrm{~m}$ cable height, length of spans from axis to axis is 3 , 4 , and 5 meters consecutively and post-tensioned force of 40 $\mathrm{KN}$. The results of the models non-linear statistical analysis are indicated in Table IV. Based on the results of the Table IV, the larger value of ductility factor is related to the $5 \mathrm{~m}$ length of span model and the smaller value of the ductility factor is for the model with 3 mlength span. Therefore, the length of the span effects the rate of the ductility factor of the steel frame with cable. We can increase the rate of the ductility factor by raising the length of the span (between 3 to 5 meters).

\section{Effect of the Primary Post-Tensioned Force}

For checking the effect of the primary post-tensioned force on the ductility of the structure, we consider three models of steel frames with cables with $2.7 \mathrm{~m}$ height, the length span from axis to axis of 4 meters and post-tensioned force of 20, 40 and 
$60 \mathrm{KN}$ consecutively. The results of non-linear statistical analysis of the models are shown in Table V. According to the results of Table $\mathrm{V}$, the larger value of ductility factor is related to the model with the primary post-tensioned force of $60 \mathrm{KN}$ and the smaller value is for the model with the primary posttensioned force of $20 \mathrm{KN}$. Therefore, the primary posttensioned force of the cables has an effect on the rate of ductility factor of the steel frame with cable. We can increase the rate of the ductility factor and consequently the seismic function of the structure by raising the primary post-tensioned force (between 20 to $60 \mathrm{KN}$ ).

TABLE IV. EFFECT OF THE LENGTH OF THE SPAN ON THE RATE OF DUCTILITY FACTOR

\begin{tabular}{|c|c|c|c|}
\hline Type of the steel frame & $\Delta \mathbf{y}(\mathbf{m})$ & $\mathbf{\Omega}$ & $\boldsymbol{\mu}$ \\
\hline $\begin{array}{c}\text { Steel frame with cable with length } \\
\text { span of 3m }\end{array}$ & 0.0065 & 1.53 & 14.22 \\
\hline $\begin{array}{c}\text { Steel frame with cable with length } \\
\text { span of 4m }\end{array}$ & 0.0063 & 1.53 & 14.66 \\
\hline $\begin{array}{c}\text { Steel frame with cable with length } \\
\text { span of 5m }\end{array}$ & 0.0055 & 1.37 & 16.79 \\
\hline
\end{tabular}

TABLE V. EFFECT OF THE PRIMARY POST-TENSIONED FORCE OF THE CABLES ON THE RATE OF THE DUCTILITY FACTOR

\begin{tabular}{|c|c|c|c|}
\hline Type of the steel frame & $\Delta \mathbf{y}(\mathbf{m})$ & $\mathbf{\Omega}$ & $\boldsymbol{\mu}$ \\
\hline $\begin{array}{c}\text { Steel frame with cable with } \\
\text { post-tensioned force of 20 KN }\end{array}$ & 0.0064 & 1.52 & 14.42 \\
\hline $\begin{array}{c}\text { Steel frame with cable with } \\
\text { post-tensioned force of 40 KN }\end{array}$ & 0.0063 & 1.53 & 14.66 \\
\hline $\begin{array}{c}\text { Steel frame with cable with } \\
\text { post-tensioned force of 60 KN }\end{array}$ & 0.0056 & 1.40 & 16.50 \\
\hline
\end{tabular}

\section{CONCLUSION}

In this study, we introduce the steel frame with reduced beam section and post-tensioned cables. Based on the results, the steel frame with cable has more ductility when compared to the normal steel frame. The findings of the current study indicate that the increased height, length of the span and primary cable post-tensioned force cause increase in the ductility factor of the structure and consequently improve its seismic behavior.

\section{REFERENCES}

[1] S. J. Chen, C. H. Yeh, J. M. Chu, "Ductile steel beam-to-column connections for seismic resistance", Journal of Structural Engineering, Vol. 122, No. 11, pp. 1292-1299, 1996

[2] N. F. Youssef, D. Bonowitz, J. L. Gross, A survey of steel momentresisting frame buildings affected by the 1994 Northridge earthquake, US National Institute of Standards and Technology, 1995

[3] M. D. Engelhardt, T. Winneberger, A. J. Zekany, T. J. Potyraj, "The dogbone connection: Part II", Modern Steel Construction, Vol. 36, No. 8, pp. 46-55, 1996

[4] C. W. Roeder, SAC program to assure ductile connection performance, Mazzolani and Tremblay, 2000

[5] J. M. Ricles, R. Sause, M. M. Garlock, C. Zhao, "Posttensioned seismicresistant connections for steel frames", Journal of Structural Engineering, Vol. 127, No. 2, pp. 113-121, 2001

[6] A. Niknam, E. Sanaee, Behavior and seismic design of steel buildings based on the regulation UBC, Hormozgan University Press, 2002
[7] M. M. Garlock, J. M., Ricles, R. Sause, "Experimental studies of fullscale posttensioned steel connections", Journal of Structural Engineering, Vol. 131, No. 3, pp. 438-448, 2005

[8] M. Khan Babaei, Investigating seismic behavior of knee bracing system in steel structure, University of Zanjan press, 2004

[9] T. Vidic, P. Fajfar, M. Fischinger, "Consistent inelastic design spectra: strength and displacement", Earthquake Engineering \& Structural Dynamics, Vol. 23, No. 5, pp. 507-521, 1994 